\begin{tabular}{|l|l|l|}
\hline \multicolumn{2}{|c|}{ PublisherInfo } \\
\hline \hline PublisherName & $:$ & BioMed Central \\
\hline \hline PublisherLocation & $:$ & London \\
\hline \hline PublisherImprintName & $:$ & BioMed Central \\
\hline \hline
\end{tabular}

\title{
Arthritis and G-protein-coupled receptor regulation
}

\begin{tabular}{||l|l|l||}
\hline \multicolumn{2}{|c||}{ ArticleInfo } \\
\hline \hline ArticleID & $:$ & 93 \\
\hline \hline ArticleDOI & $:$ & $10.1186 /$ ar-2001-68081 \\
\hline \hline ArticleCitationID & $:$ & 68081 \\
\hline \hline ArticleSequenceNumber & $:$ & 50 \\
\hline \hline ArticleCategory & $:$ & Paper Report \\
\hline \hline ArticleFirstPage & $:$ & 1 \\
\hline \hline ArticleLastPage & $:$ & 3 \\
\hline \hline & & RegistrationDate $: 2001-7-26$ \\
ArticleHistory & $:$ & Received \\
& Accepted $2001-3-28$ \\
& $: 2001-7-26$ \\
\hline \hline ArticleCopyright & $:$ & Biomed Central Ltd2001 \\
\hline \hline ArticleGrants & $:$ & \\
\hline \hline
\end{tabular}




\begin{tabular}{|l|l|l||}
\hline ArticleContext & $: 130753311$ \\
\hline
\end{tabular}

Jose L Pablos, ${ }^{\text {Aff1 }}$

Aff1 Hospital 12 de Octubre, Madrid, Spain

\section{Keywords}

Arthritis, G-proteins, protein kinases

\section{Context}

G-protein-coupled receptors (GPCRs) mediate cellular responses to a large variety of mediators of immune and inflammatory processes such as chemokines, prostanoids or hormones. GPCR signal transduction through $\mathrm{G}$ proteins is tightly regulated by agonist-induced desensitization. Protein kinases, phosphatases, endocytosis and recycling play various roles in direct and cross-desensitization of these receptors. Natural mechanisms of turning off signaling by GPCRs are potential targets for antiinflammatory or immunomodulatory therapies. The authors explore the regulation of GPCR kinases (GRKs) and arrestins, the proteins involved in desensitization of GPCRs, during the development of adjuvant arthritis.

\section{Significant findings}

During adjuvant arthritis in rats, both $\mathrm{T}$ and $\mathrm{B}$ cells from secondary immune organs (spleen and lymph nodes) displayed a dramatic reduction in the enzymatic activity and levels of the main GRKs expressed in leukocytes, GRK2, GRK3 and GRK6, while ?-arrestin-1 levels were increased. All proteins returned to normal levels after arthritis resolved. Changes in GRK protein expression occurred at the post-transcriptional level, since no changes in mRNA levels were detected. These changes were specific to secondary lymphoid organs and did not occur in other organs such as thymus, heart or pituitary.

\section{Comments}


GRKs provide a natural negative feedback that limits GPCR activation by their agonists. GRKs are responsible for the rapid phosphorylation of activated GPCRs that facilitates the subsequent binding of arrestins. This binding induces uncoupling of the receptor from the G protein. Accordingly, GRKs are upregulated in diseases characterized by overstimulation of GPCRs such as hypertension, heart failure or opioid addiction. In contrast, the downregulation reported in this model, as well as in leukocytes from rheumatoid arthritis patients in another study by the same authors (see Additional information), provides a molecular basis for the persistent responsiveness of GPCRs in spite of their prolonged stimulation during chronic immune activation. This is the first evidence of abnormal downregulation of GRKs during chronic immune activation. Whether this is specific to chronic arthritis or a nonspecific phenomenon associated with chronic immune-mediated processes remains to be investigated.

\section{Methods}

Adjuvant arthritis induction in Lewis rats, analysis of GRK activity in tissue extracts by lightdependent phosphorylation of rhodopsin, northern and western blot

\section{Additional information}

Lombardi MS, Kavelaars A, Schedlowski M, Bijlsma JW, Okihara KL, Van de Pol M, Ochsmann S, Pawlak C, Schmidt RE, Heijnen CJ: Decreased expression and activity of G-protein-coupled receptor kinases in peripheral blood mononuclear cells of patients with rheumatoid arthritis. FASEB J 1999, 13:715-725 (PubMed abstract).

\section{References}

1. Lombardi MS, Kavelaars A, Cobelens PM, Schmidt RE, Schedlowski M, Heijnen CJ: Adjuvant arthritis induces down-regulation of $\mathrm{G}$ protein-coupled receptor kinases in the immune system. J Immunol. 2001, 166: 1635-1640.

This PDF file was created after publication. 